\title{
Spontaneous perforation of the common bile duct: A rare case
}

\author{
Spontan koledok perforasyonu: Nadir bir olgu
}

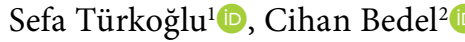 \\ ${ }^{1}$ Department of Radiology, Denizli State Hospital, Denizli, Turkey \\ ${ }^{2}$ Department of Emergency Medicine, University of Health Sciences, Antalya Training and Research Hospital, Antalya, Turkey
}

\begin{abstract}
Spontaneous common bile duct perforation is a rare cause of acute abdomen. Preoperative diagnosis is rare. The etiology is unclear, but the proposed theories include congenital, trauma, necrotizing enterocolitis, intramural thrombosis, iatrogenic, or bile duct stones. In this article, we report a case of common bile duct perforation in a 13-month-old female patient without any medical or traumatic history. Although it is a very rare disease, emergency physicians should consider common bile duct in patients with complaints of abdominal pain, distention, nausea, vomiting, and fever. An overlooked diagnosis or misdiagnosis can be potentially fatal.

Keywords: Abdominal pain; common bile duct; perforation.
\end{abstract}

öz

Spontan koledok perforasyonu, akut karnın nadir bir nedenidir. Ameliyat öncesi tanı nadirdir. Etyolojisi açık değildir, fakat teoriler doğuştan, travma, nekrotizan enterokolit, intramural tromboz, iyatrojenik veya koledokta taştır. Bu yazıda, 13 aylık herhangi bir tıbbi veya travma öyküsü olmayan bir kız hastada koledok perforasyonunu olgusu sunuldu. Çok nadir görülen bir hastalık olmasına rağmen, acil hekimleri karın ağrısı, şişkinlik, mide bulantısı, kusma ve ateş şikayetleri olan hastalarda koledok rüptürünü akılda tutmalıdırlar. Gözden kaçan veya yanlış bir tanı, potansiyel olarak ölümcül olabilir. Anahtar sözcükler: Karın ağrısı; koledok; perforasyon.

Spontaneous common bile duct (CBD) perforation is a rare clinical entity in children. ${ }^{[1]}$ The diagnosis of spontaneous CBD perforation is based on a non-specific symptomatology so it may often be delayed and undiagnosed prior to laparotomy. ${ }^{[2]}$ The etiology is unclear, but the proposed theories include congenital weakness of $\mathrm{CBD}$, trauma, necrotizing enterocolitis, intramural thrombosis, iatrogenic, or stone in the CBD. ${ }^{[3,4]}$ In this case report, we would like to highlight a case of CBD in a patient without any medical or traumatic history.

\section{CASE REPORT}

A 13-month-old girl with no previous medical problems was admitted to emergency medicine for acute abdomen. She had complaints of lethargy for three days, poor appetite, and two episodes of non-bilious vomiting. Over the next three days, the child developed abdominal pain, distention, and fever. On examination, she was pale, tachypneic, dehydrated, and not jaundiced. The abdomen was distended and tender. There was no organomegaly. Initial laboratory studies revealed a 


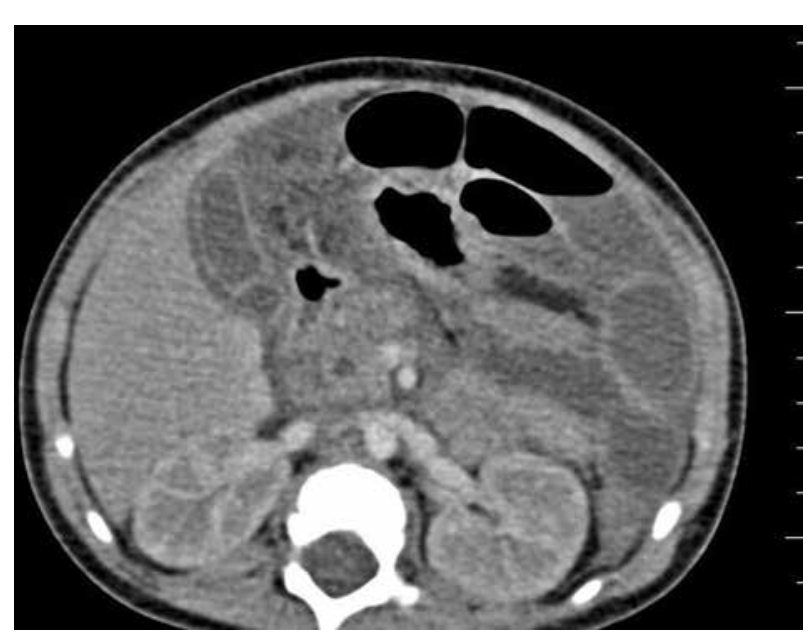

Figure 1. Axial computed tomography scan of the abdomen showing thickened gall bladder with pericholecystic fluid collection, dilated common bile duct, and segmental dilatation of ileum-jejunum.

white blood cell (WBC) count of $14.3 \times 10^{3} / \mathrm{mm}^{3}$ (normal range: $4 \times 10^{3}-10 \times 10^{3}$ ) with a left shift of $83.4 \%$, hematocrit level of $34.7 \%$ (normal range: $37-47 \%$ ), and platelet count of $467 \times 10^{3} / \mathrm{mm}^{3}$ (normal range: $142 \times 10^{3}-424 \times 10^{3}$ ). The blood biochemical test results were as follows: Blood urea nitrogen: $24 \mathrm{mg} / \mathrm{dL}$; Creatinine: $0.41 \mathrm{mg} / \mathrm{dL} ;$ Aspartate aminotransferase: 92 IU/L; Alanine aminotransferase: $54 \mathrm{IU} / \mathrm{L}$; Lactate dehydrogenase: 365 IU/L; Total/direct bilirubin: 1.76/0.96 mg/dL; C-reactive protein: $124.7 \mathrm{mg} / \mathrm{L}$. Serial abdominal radiographs showed stagnant bowel loops. Ultrasonography (USG) of the abdomen revealed a grossly distended gall bladder with pericholecystic fluid collection and a dilated $\mathrm{CBD}$ extending to the intrapancreatic portion. Computed tomography (CT) scan of the abdomen was performed as the symptoms worsened. This revealed significant ascites as well as dilated CBD $(8.5 \mathrm{~mm})$ and thickening of the gall bladder wall with pericholecystic fluid collection (Figure 1, 2). Laparotomy was performed and extensive bile staining of abdominal viscera was noted with a perforation on the lateral wall of the CBD, which appeared to be mildly dilated. The liver was unremarkable and the gall bladder was distended. A cholecystectomy was performed and $\mathrm{T}$ tube as placed into the perforation and the perforation closed around this. This patient was alive and well six months after the operation.

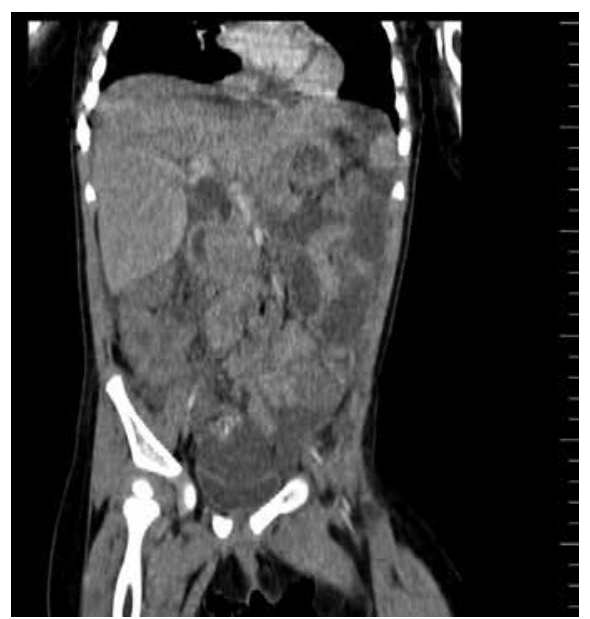

Figure 2. Coronal computed tomography scan of abdomen showing pericholecystic, pelvic and paracolic fluid collection.

\section{DISCUSSION}

Spontaneous common bile duct perforation is a rare clinical entity in both adults and children. The causes are various and include spontaneous or idiopathic causes, anomalies of the pancreaticobiliary ductal system, congenital, trauma, choledochal cyst, infection, necrotizing enterocolitis, and iatrogenic. ${ }^{[1,3,5]}$ The etiology of spontaneous perforation of $\mathrm{CBD}$ is unclear, however the proposed theories include congenital, ischemia, distal biliary obstruction, pancreaticobiliary malunion, and infection. The condition is mostly diagnosed intraoperatively. ${ }^{[3,5]}$

The presentation of $\mathrm{CBD}$ perforation may be acute or insidious; the insidious type being more common (80\%). ${ }^{[5]}$ The acute form is characterized by fever, severe abdominal pain, vomiting, gastric outlet obstruction peritonitis, toxemia, and shock. The insidious presentation includes progressive jaundice, painless abdominal distension, and clay colored stool. ${ }^{[5,6]}$ Our patient had similar complaints in the early days of the disease.

As mentioned before, preoperative diagnosis is difficult and various imaging modalities such as abdominal USG, CT scanning, magnetic resonance imaging, and radionuclide scanning aids. Laboratory assessments are not pathognomonic but conjugated bilirubin and alkaline phosphatase levels may be elevated. Ultrasound will show free or loculated intraperitoneal fluid with normal intra- and extra-hepatic ducts. ${ }^{[3,5,7]}$ In our case, a 
increase in the WBC count and conjugated bilirubin was detected. Common bile duct perforation should also be considered if the patient presents with acute abdomen symptoms with elevated conjugated bilirubin and pericolic fluid shown in USG and CT imaging.

The recommended treatment for such cases is simple drainage with or without suture closure, $\mathrm{T}$ tube drainage, and/or cholecystostomy. In patients with distal obstruction of the $\mathrm{CBD}$, biliary enteric bypass should be performed. Primary suture repair of the $\mathrm{CBD}$ is considered unnecessary and even dangerous because of local inflammation. ${ }^{[6-8]}$

Although it is a very rare disease, emergency physicians should consider CBD in patients with complaints of abdominal pain, distention, nausea, vomiting and fever. An overlooked diagnosis or misdiagnosis can be potentially fatal.

\section{Declaration of conflicting interests}

The authors declared no conflicts of interest with respect to the authorship and/or publication of this article.

\section{Funding}

The authors received no financial support for the research and/or authorship of this article.

\section{REFERENCES}

1. Kanojia RP, Sinha SK, Rawat J, Wakhlu A, Kureel S, Tandon R. Spontaneous biliary perforation in infancy and childhood: clues to diagnosis. Indian $J$ Pediatr 2007;74:509-10.

2. Dash AP, Mishra T, Mohapatra M, Ibrarullah M. Spontaneous perforation of bile duct. Trop Gastroenterol 2012;33:151-3.

3. Mirza B, Ijaz L, Saleem M, Iqbal S, Sharif M, Sheikh A. Management of biliary perforation in children. Afr J Paediatr Surg 2010;7:147-50.

4. Evans K, Marsden N, Desai A. Spontaneous perforation of the bile duct in infancy and childhood: a systematic review. J Pediatr Gastroenterol Nutr 2010;50:677-81.

5. Lal S, Yedalwar V. Spontaneous perforation of the common bile duct in a toddler: a diagnostic dilemma. J Gastroenterol Hepatol Res 2013;2:706-8.

6. Rege SA, Lambe S, Sethi H, Gandhi A, Rohondia $\mathrm{O}$. Spontaneous common bile duct perforation in adult: a case report and review. Int Surg 2002;87:81-2.

7. Çelebi F, Balık AA, YıldırganMi, Demirci N, Ören D. Spontan koledok perforasyonu. Turkiye Klinikleri $\mathrm{J}$ Med Sci 2002;22:56-8.

8. Kasat LS, Borwankar SS, Jain M, Naregal A. Spontaneous perforation of the extrahepatic bile duct in an infant. Pediatr Surg Int 2001;17:463-4. 